\title{
FAKTOR-FAKTOR YANG MEMPENGARUHI KESUKSESAN IMPLEMENTASI SISTEM INFORMASI (STUDI KASUS SISTEM INFORMASI AKADEMIK STKIP MUHAMMADIYAH PRINGSEWU LAMPUNG)
}

\author{
Susilo Hartono \\ Universitas Muhammadiyah Pringsewu \\ susilo.hartono2009@gmail.com
}

\begin{abstract}
This research used the success model of information system from Delone and Mc. Lean which has been modified based on the need and the situation at STKIP Muhammadiyah Pringsewu. The respondents were the first year students in the academic year 2012-2013 and the operators of SIAKAD. The number of the respondents were 196 students and 10 operators. The process of validity and reliability and the hyphotesa used Structural Equation Modeling (SEM). Which is analysed using Amos 20 software.

The result of this research showed that from 5 hyphotesis which have been formulated, four of them were received. These hypothesis are the following : the quality of information influence the satisfying of the user; the quality of the system influence the satisfying of the user; the trust influence the satisfying of the user; and the satisfying of the user influence the benefits of the SIAKAD. On the other hard, the quality of the service doesn't has significant influence to the satisfying of the SIAKAD user. The success factors, which were resulted in this research, will be used as the suggestion and recomendation in the next SIAKAD development so that the sevice quality of SIAKAD to the students will increase.
\end{abstract}

Keywords: Information Systems Success; DeLone and McLean Model; Structural Equation Modeling (SEM); AMOS.

\begin{abstract}
Abstrak
Penelitian dilakukan dengan menggunakan model kesuksesan sistem informasi dari DeLone \& McLean, yang telah di modifikasi sesuai dengan kebutuhan dan keadaaan yang ada di STKIP MPL. Responden dalam penelitian sebanyak 196 responden yang terdiri dari Mahasiswa angkatan 2012 dan 10 operator SIAKAD. Proses validasi dan reliability model serta pengujian hipotesa-hipotesa menggunakan Structural Equation Modeling (SEM) yang di analisis menggunakan software Amos 20.

Hasil dari penelitian menunjukkan bahwa dari 5 (lima) hipotesa yang dirumuskan, terdapat 4 (empat) hipotesa yang diterima. Hipotesis tersebut adalah kualitas infromasi berpengaruh terhadap kepuasan pengguna, kualitas sistem berpengaruh terhadap kepuasan pengguna, kepercayaan berpengaruh terhadap kepuasan pengguna dan kepuasan pengguna berpengaruh kepada manfaat-manfaat bersih. Sedangkan kualitas layanan tidak berpengaruh secara signifikan terhadap kepuasan pengguna SIAKAD. Faktor-faktor kesuksesan yang dihasilkan dalam penelitian ini nantinya akan digunakan sebagai masukan dan rekomendasi dalam pengembangan SIAKAD selanjutnya. Sehingga dapat lebih meningkatkan layanan SIAKAD kepada mahasiswa.
\end{abstract}

Kata kunci: Kesuksesan Sistem Informasi; Model DeLone \& McLean; Structural Equation Modeling (SEM); AMOS

\section{PENDAHULUAN}

STKIP Muhammadiyah Pringsewu Lampung (STKIP MPL) sebagai salah satu Perguruan Tinggi di kabupaten Pringsewu sedang mengembangkan SIAKAD yang terintegrasi ke semua bagian (BAU, BAAK, Perpustakaan, Prodi, 
Laboratorium) untuk membantu pekerjaan dalam mengelola kegiatan akademik, hal ini dilakukan untuk meningkatkan pelayanan akademik dilingkungan STKIP MPL.

Seiring dengan meningkatnya jumlah mahasiswa di STKIP MPL, maka dibutuhkan Sistem informasi akademik yang dapat melayani dengan baik seluruh kegiatan akademik mahasiswa. SIAKAD yang sedang dikembangkan di STKIP MPL belum dapat diketahui apakah Sistem Informasi tersebut dapat mengakomodir semua kebutuhan pengguna. Dalam hal ini mahasiswa untuk lebih meningkatkan pelayanan di bidang akademik.

Penelitian ini dilakukan untuk mengetahui faktor-faktor yang mempengaruhi kesuksesan implementasi sistem informasi akademik. Penelitian tersebut menggunakan kerangka pemikiran yang mengadopsi model Structural Equation Modeling (SEM).

Pengembangan Sistem Informasi akademik yang ada di lingkungan STKIP MPL adalah proses pelayanan akademik dilakukan secara komputerisasi dari mulai PMB sampai dengan mahasiswa di wisuda. Pada awal pengembangan system, semua kegiatan berjalan dengan baik, seiring dengan meningkatnya jumlah mahasiswa di STKIP MPL, pihak Lembaga mulai kesulitan dalam menerapkan sistem yang sudah terhubung kesemua bagian yang terkait dengan akademik.

\section{KERANGKA TEORI}

\subsection{Model DeLone \& McLean}

Model dasar yang diperkenalkan oleh DeLone \& McLean, merumuskan bahwa terdapat 6 (enam) faktor utama yang menentukan tingkat kesuksesan sebuah sistem informasi, Ke-enam faktor tersebut adalah: kualitas sistem (system quality), kualitas informasi (information quality), penggunaan (use), kepuasan pengguna (user satisfaction), dampak individual (individual impact), dampak organisasi (organization impact). Menurut Al-Hakim (2007) kualitas informasi memiliki multidimensi, hal ini berarti bahwa organisasi dapat menggunakan berbagai pengukuran untuk mengevaluasi kualitas dari informasi dan data tersebut. Wang dkk (1995) dapat mengidentifikasi 26 dimensi kualitas informasi yang diklasifikasikan menjadi internal view (design operation) dan external view (use dan value).

\subsection{Structural Equation Modeling (SEM)}

Menurut Santoso, S. (2011), Structural Equation Modeling (SEM) merupakan model persamaan struktural yang menggambarkan hubungan antar variabel, menggabungkan antara regresi berganda dengan analisis faktor, termasuk teknik-teknik efektif untuk mengatasi multikolinearitas dan metode untuk menghitung data responden.

SEM adalah teknik statistik multivariant yang merupakan kombinasi antara analisis faktor dan analisis regresi (korelasi) yang bertujuan untuk menguji hubungan-hubungan antar-variabel yang ada pada sebuah model, baik itu antar indikator dengan konstruknya, ataupun antar konstruk.

Untuk lebih memudahkan dalam analisis model SEM, maka digunakan sebuah software statistik, yaitu Analysis of Moment Structures (AMOS), AMOS lebih sering digunakan karena lebih mudah berinteraksi (user friendly) sehingga dapat digunakan bagi pemula yang akan menggunakan SEM pada penelitiannya.

AMOS digunakan sebagai pendekatan umum analisis data dalam model persamaan SEM, dengan menggunakan AMOS maka perhitungan rumit dalam SEM akan jauh lebih mudah, cepat dalam membuat spesifikasi, melihat serta melakukan modifikasi model secara grafik dengan menggunakan tool yang sederhana. Dalam gambar berikut terlihat jelas bahwa dengan menggunakan AMOS kita dapat menentukan, melihat dan memodifikasi model SEM yang dibuat 
secara visual (graphic model). AMOS Analysis of Moment Structures merupakan salah satu software yang diguanakan untuk mengestimasi model pada model persamaan struktural (Ghozali, 2004).

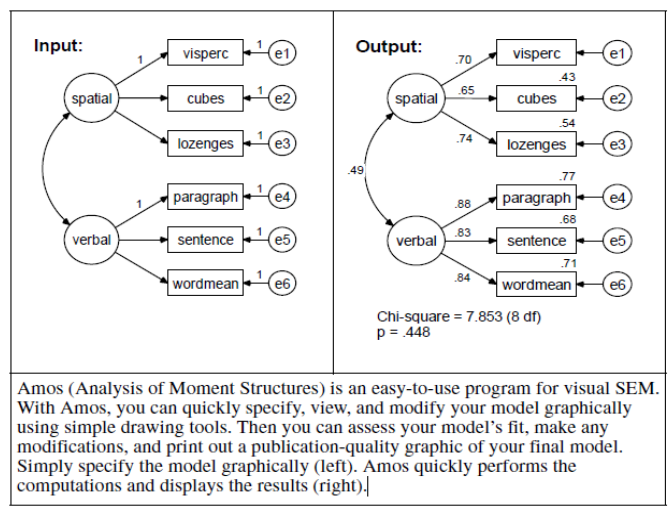

Gambar 1. Mengolah SEM Dengan Menggunakan AMOS

\subsection{Kerangka Berpikir}

Berdasarkan teori dan penelitian di atas penulis mencoba merumuskan model beserta hipotesis-hipotesis yang akan digunakan untuk menguji apakah variabel-variabel yang ada di dalam model DeLone \& McLean juga berpengaruh terhadap kesuksesan implementasi Sistem Informasi Akademik (SIAKAD) STKIP Muhammadiyah Pringsewu Lampung.

Sistem informasi yang bersifat wajib (mandatory) tingkat penggunaan (use) memberikan sedikit informasi tentang keberhasilan sistem, sehingga dapat dihilangkan dari model. Terdapat 6 variabel yang akan diuji, yaitu kualitas informasi (information quality), kualitas sistem (system quality), kualitas layanan (service quality), kepuasan pengguna (user satisfaction), manfaat-manfaat bersih (net benefits) dan menambahkan variabel kepercayaan (trust) dalam hal ini kepercayaan terhadap informasi yang dihasilkan SIAKAD, akses dan keamanan teknologi informasi yang ada di STKIP Muhammadiyah Pringsewu Lampung.

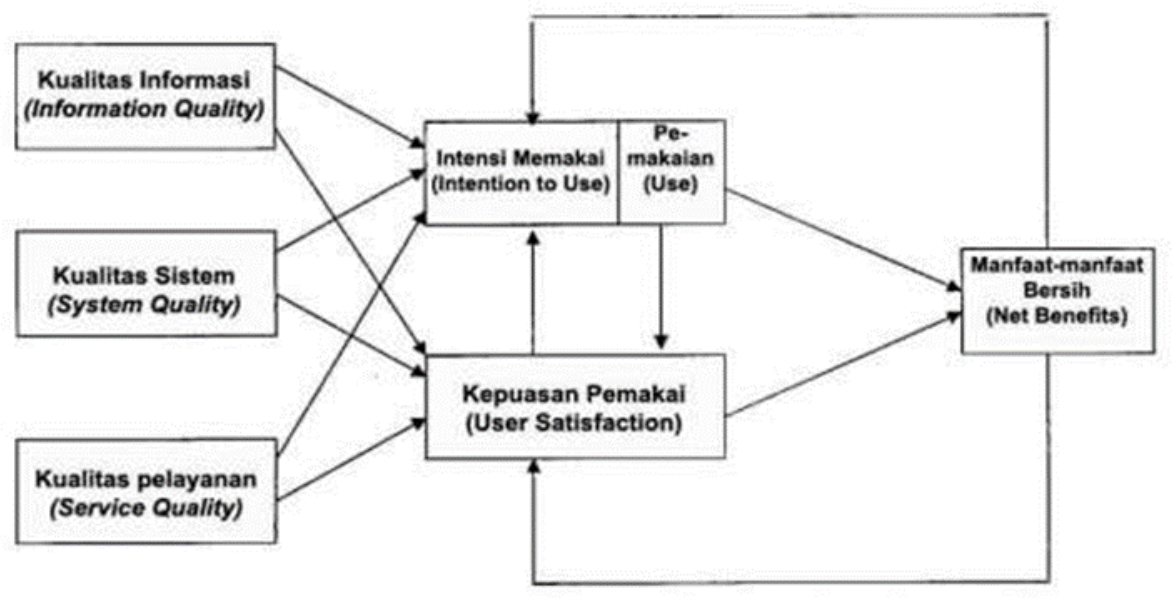

Gambar 2. Model Penelitian DeLone \& McLean

Dari rumusan kerangka berpikir di atas, maka penulis mengajukan 5 (lima) buah hipotesa yang akan diuji dalam penelitian, yaitu:

Hipotesa 1 (H1): Menunjukkan bahwa kualitas informasi secara signifikan berpengaruh positif terhadap kepuasan pengguna. 
Hipotesa 2 (H2): Menunjukkan bahwa kualitas sistem secara signifikan berpengaruh positif terhadap kepuasan pengguna

Hipotesa 3 (H3): Menunjukkan bahwa kualitas layanan secara signifikan berpengaruh positif terhadap kepuasan pengguna

Hipotesa $4(\mathrm{H} 4)$ : Menunjukkan bahwa kepercayaan secara signifikan berpengaruh positif terhadap kepuasan pengguna

Hipotesa 5 (H5): Menunjukkan bahwa Kepuasan pengguna secara segnifikan berpengaruh positif terhadap manfaatmanfaat bersih.

\section{METODOLOGI}

Metodologi yang digunakan pada penelitian ini dijelaskan dengan bagan berikut:

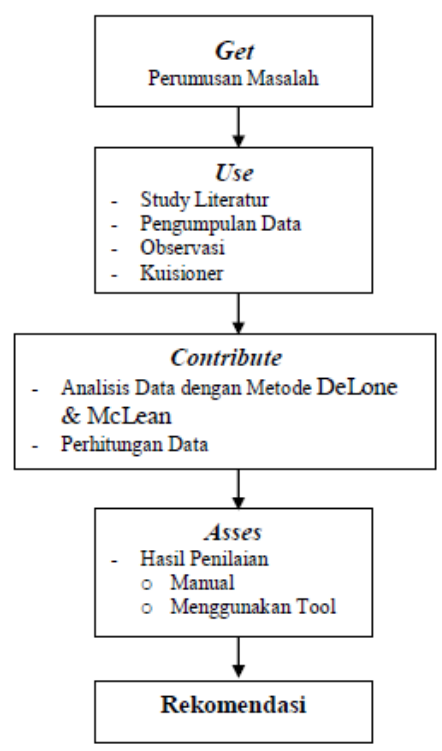

Gambar 3. Metodologi Penelitian

\subsection{Perumusan Masalah}

Dari hasil wawancara dan studi pustaka yang dilakukan maka didapatkan informasi tentang latar belakang serta identifikasi permasalahan sehingga dapat dirumuskan research question, tujuan dan manfaat penelitian, ruang lingkup penelitian.

\subsection{Studi Literatur}

Dari hasil tahapan perumusan masalah telah dihasilkan research question dan batasan masalah dalam penelitian ini. Untuk dapat menjawab reseach question tersebut perlu dilakukan studi literatur, yaitu dengan melakukan proses pengkajian terhadap metodologi dan tools yang digunakan dalam pengolahan data penelitian serta review dari beberapa hasil penelitian sebelumnya yang berhubungan dengan penelitian. 


\subsection{Pengolahan Data dan Analisis}

\subsubsection{Variabel Penelitian}

Berdasarkan kerangka penelitian yang telah dirumuskan, terdapat 6 (enam) variabel yang digunakan yaitu : kualitas informasi (information quality), kualitas sistem (system quality), kualitas layanan (service quality), kepercayaan (trust), kepuasan pengguna (user satisfaction) dan manfaat-manfaat bersih (net benefits).

\subsubsection{Perancangan Kuesioner}

Setiap pertanyaan diberikan skala penilaian menggunakan skala likert yang terbagi menjadi 5 tingkatan yaitu sangat setuju (SS) bernilai 5, setuju (S) bernilai 4, netral (N) bernilai 3, tidak setuju (TS) bernilai 2, dan sangat tidak setuju (ST) bernilai 1.

\subsubsection{Penentuan Sampel Data}

Pada penelitian ini populasi sampel yang digunakan adalah responden dari pengguna SIAKAD, yaitu mahasiswa, dosen dan operator, dengan berbagai jenis user level.

Penentuan jumlah sample berdasarkan tabel Krejcie \& Morgan, dimana untuk populasi sejumlah 500 orang (data mhs baru reguler per september 2012 dan level pengguna SIAKAD yang lain) diperlukan minimal 217 orang sebagai responden

\subsubsection{Analisis Data}

Pada tahap analisis dilakukan perhitungan data-data yang didapat dari hasil pengumpulan data, selanjutnya hasil kuesioner tersebut diolah menggunakan Structural Equation Modeling (SEM) dengan bantuan software Analysis of Moment Structures (AMOS).

\section{HASIL DAN PEMBAHASAN}

Model penelitian dirumuskan berdasarkan teori-teori dan model-model dari penelitian sebelumnya yang membahas tentang penilaian dan pengukuran kesuksesan sistem informasi. Kemudian akan dilakukan analisis terhadap model yang dibuat serta melakukan pengujian model dengan menggunakan data-data kuesioner yang didapat. Peneliti melakukan uji validitas, realibilitas dan modifikasi model menggunakan bantuan software AMOS, untuk lebih jelasnya rumusan model kerangka berpikir dapat dilihat pada gambar berikut:

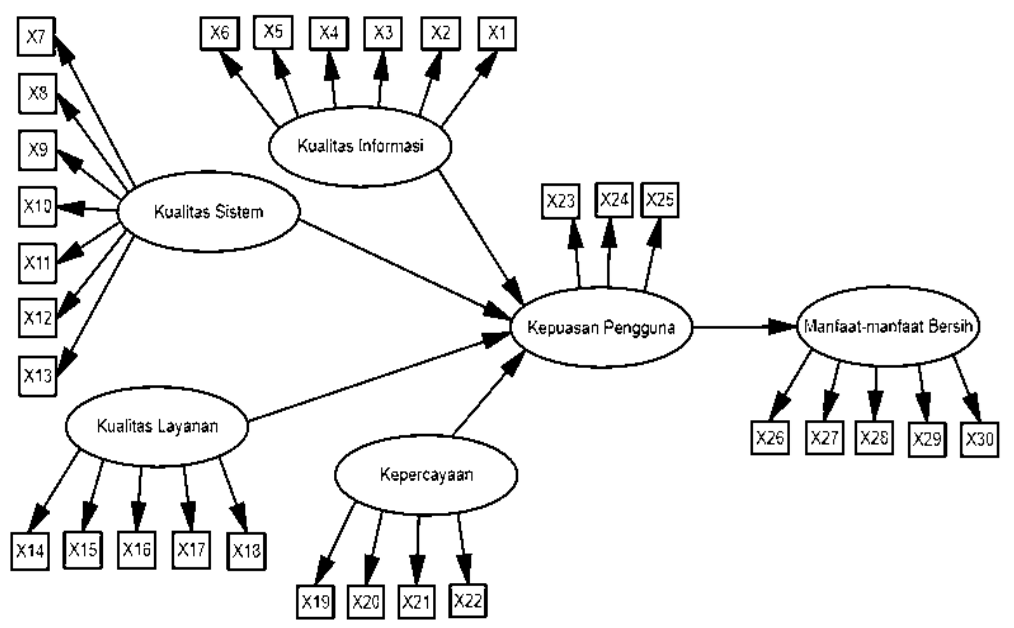

Gambar 4. Rumusan Kerangka Berpikir (Confirmation Model) 


\subsection{Uji Validitas Model}

Uji validitas model menggunakan metode Maximum Likelihood (ML), metode ini digunakan pada rentang ukuran sampel antara 100-200, pada penelitian ini ukuran sampel berada pada rentang ukuran tersebut. Dengan melakukan uji Goodness of Fit Index (GFI) pada AMOS, langkah-langkah yang dilakukan adalah normalisasi data, modifikasi model dengan uji regression weights dan standardized regression weights sehingga nantinya didapatkan nilai GFI yang baik $(\geq 0,90)$.

Setelah dilakukan modifikasi model pada variabel endogen, keseluruhan index hasil penilaian GFI terhadap model modifikasi untuk variabel endogen sudah bernilai baik, artinya model yang dibuat dapat diterima dengan baik atau sudah valid, dapat dilihat pada tabel berikut:

Tabel 1. Pengujian GFI Terhadap Confirmation Model Variabel Endogen

\begin{tabular}{cccc}
\hline Item penilaian & Hasil Uji Model & GFI & Keterangan \\
\hline Chi-Squares & 6,014 & kecil & Baik \\
Probability &, 11 & $\geq 0,05$ & Baik \\
CMIN/DF & 2,00 & $\leq 2,0$ & Baik \\
RMSEA &, 083 & $\geq 0,08$ & Baik \\
GFI &, 990 & $\geq 0,90$ & Baik \\
AGFI &, 881 & $\geq 0,90$ & Baik \\
TLI &, 959 & $\geq 0,95$ & Baik \\
CFI &, 996 & $\geq 0,95$ & Baik \\
\hline
\end{tabular}

Modifikasi model dilakukan dengan menghilangkan beberapa indikator pada variabel kualitas informasi, kualitas sistem, kualitas layanan dan kepercayaan dengan bantuan software AMOS. Sehingga dihasilkan construct full model yaitu hasil analisis dan pengembangan dari confirmatory model yang dapat dilihat pada gambar berikut:

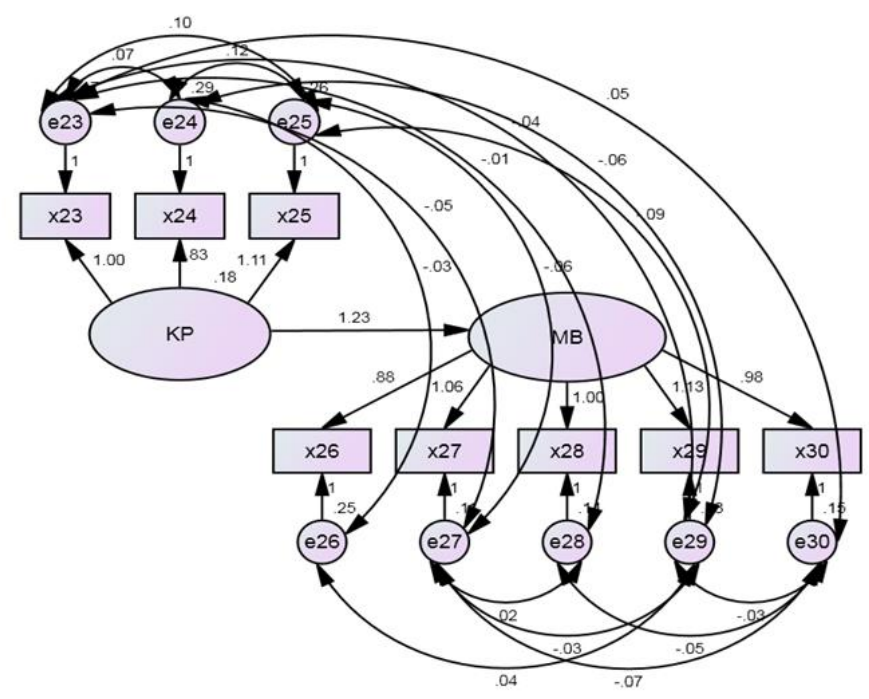

Gambar 5. Modifikasi Model Pada Variabel Endogen (Construct Full Model)

Pada pengujian regression weights terhadap model akhir (construct full model) didapatkan hasil bahwa jalur (path) dari kualitas layanan menuju kepuasan pengguna tidak signikan, hal ini karena nilai c.r $=-2,65($ signifikan $>2,0)$ dan $\mathrm{p}=0,08$ (signifikan $<0,05$ ), sehingga jalur ini harus dihilangkan.

Hasil pengujian regression weights terhadap construct full model dapat dilihat pada tabel berikut: 
Tabel 2. Uji Regression Weights Terhadap Construct Full Model

\begin{tabular}{lllrrrrl}
\hline & & & Estimate & S.E. & C.R. & P & Label \\
\hline KP & $<---$ & KS & .329 & .058 & 5.688 & $* * *$ & par_16 \\
KP & $<---$ & K & .686 & .090 & 7.618 & $* * *$ & par_19 \\
KP & $<---$ & KI & .441 & .081 & 5.477 & $* * *$ & par_20 \\
KP & $<---$ & KL & -.163 & .062 & -2.652 & .008 & par_24 \\
MB & $<---$ & KP & 1.000 & .133 & 8.011 & $* * *$ & par_7 \\
\hline
\end{tabular}

Setelah dilakukan modifikasi model dengan menghapus variabel kepercayaan yang menuju ke variabel kepuasan pengguna, maka diperoleh model akhir dari penelitian ini seperti yang dapat dilihat pada gambar berikut:

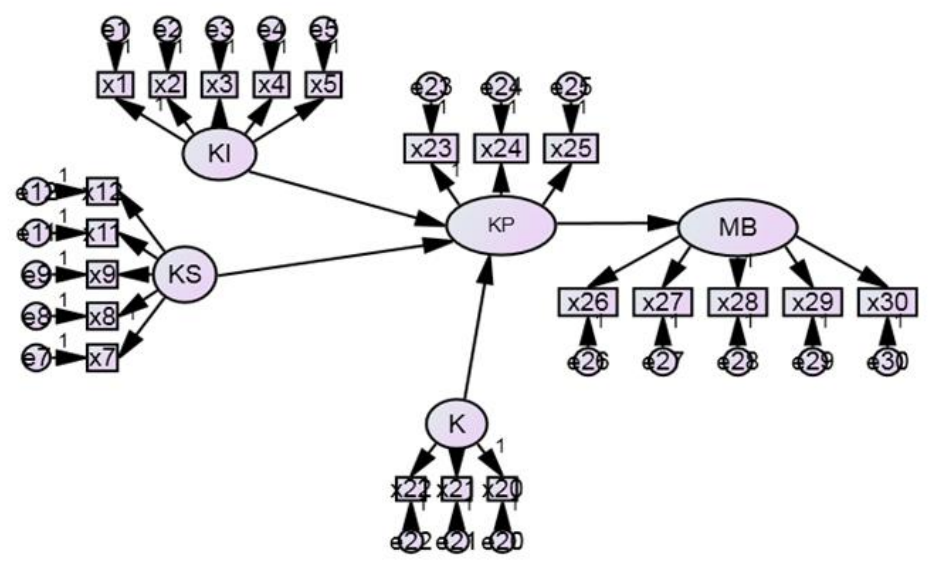

Gambar 6. Model Akhir Penelitian

Berdasarkan model akhir penelitian di atas menunjukkan bahwa kesuksesan Sistem Informasi Akademik di STKIP Muhammadiyah Pringsewu Lampung dipengaruhi oleh 5 (lima) variabel yaitu: Kualitas Informasi, Kualitas Sistem, Kualitas Layanan, Kepuasan Pengguna dan Manfaat Bersih.

\subsection{Uji Reliabilitas}

Pengujian reliabilitas dilakukan untuk menunjukkan bahwa dalam sebuah model, indikator-indikator yang digunakan memiliki derajat kesesuaian yang baik dengan nilai yang konsisten.

Uji reliabilitas dilakukan dengan menggunakan rumus:

$$
\text { Construct Reability }=\frac{[\Sigma \text { Standardize Loading }]^{2}}{[\Sigma \text { Standardize Loading }]^{2}+\Sigma \varepsilon j}
$$


Tabel 3. Hasil Uji Reliabilitas

\begin{tabular}{lccr}
\hline \multicolumn{1}{c}{ Variabel } & Nstd.loading & $\sum \varepsilon j$ & Reliability \\
\hline Kualitas Informasi & 3.35 & 2.75 & 0.80 \\
Kualitas Sistem & 3.52 & 2.51 & 0.83 \\
Kepercayaaan & 2.32 & 3.20 & 0.63 \\
Kepuasan Pengguna & 5.07 & -0.19 & 1.01 \\
Manfaat Bersih & 3.80 & 1.38 & 0.91 \\
\hline
\end{tabular}

Dapat dilihat pada Tabel 4.30 bahwa perhitungan reliability untuk setiap variabel memiliki nilai $\geq 0,7$ (toleransi 0,05 - 0,6), sehingga dapat dikatakan seluruh indikator yang ada dalam construct model sudah reliabel.

\subsection{Hasil Pengujian Hipotesis}

Dengan menggunakan model akhir yang didapat, maka selanjutnya dilakukan pengujian hipotesa penelitian, yaitu bahwa kualitas informasi berpengaruh terhadap kepuasan pengguna (H1), kualitas sistem berpengaruh terhadap kepuasan pengguna (H2), kualitas layanan berpengaruh terhadap kepuasan pengguna (H3), kepercayaan berpengaruh terhadap kepuasan pengguna (H4), kepuasan pengguna berpengaruh terhadap manfaat bersih (H5).

Hipotesa 1 (H1) : Menunjukkan bahwa Kualitas informasi secara segnifikan berpengaruh positif terhadap kepuasan pengguna.

Berdasarkan pengujian model yang telah dilakukan, didapatkan bahwa kualitas informasi berpengaruh positif terhadap kepuasan pengguna, hal ini ditunjukkan dengan nilai c.r $=5.477$ (signifikan $>2,0$ ) dan $\mathrm{p}=* * *(<0,05)$ sehingga hipotesa 1 dapat diterima.

Hipotesa $2(\mathrm{H} 2)$ : Menunjukkan bahwa Kualitas sistem secara segnifikan berpengaruh positif terhadap kepuasan pengguna.

Berdasarkan pengujian model yang telah dilakukan, didapatkan bahwa kualitas informasi berpengaruh positif terhadap kepuasan pengguna, hal ini ditunjukkan dengan nilai c.r=5.688 (signifikan $>2,0)$ dan $\mathrm{p}=* * *(<0,05)$ sehingga hipotesa 2 dapat diterima.

Hipotesa 3 (H3) : Menunjukkan bahwa Kualitas layanan secara segnifikan berpengaruh positif terhadap kepuasan pengguna.

Berdasarkan pengujian model yang telah dilakukan, didapatkan bahwa kualitas Layanan tidak berpengaruh positif terhadap kepuasan pengguna, hal ini ditunjukkan dengan nilai c.r $=-2,652$ tidak signifikan $(\operatorname{signifikan}>2,0)$ dan $p=, 008$ tidak signifikan $(<0,05)$ sehingga hipotesa 3 ditolak.

Hipotesa 4 (H4) : Menunjukkan bahwa Kepercayaan secara segnifikan berpengaruh positif terhadap kepuasan pengguna.

Berdasarkan pengujian model yang telah dilakukan, didapatkan bahwa kepercayaan berpengaruh positif terhadap kepuasan pengguna, hal ini ditunjukkan dengan nilai c.r=7.618 (signifikan $>2,0)$ dan $\mathrm{p}=* * *(<0,05)$ sehingga hipotesa 4 dapat diterima.

Hipotesa 5 (H5) : Menunjukkan bahwa Kepuasan pengguna secara segnifikan berpengaruh positif terhadap manfaat-manfaat bersih. 
Berdasarkan pengujian model yang telah dilakukan, didapatkan bahwa kepuasan pengguna berpengaruh positif terhadap manfaat bersih, hal ini ditunjukkan dengan nilai c.r $=8.011$ (signifikan $>2,0)$ dan $\mathrm{p}=* * *(<0,05)$ sehingga hipotesa 5 dapat diterima.

Rangkuman hasil uji hipotesis dapat dilihat pada tabel berikut:

Tabel 4. Hasil Pengujian Hipotesis Penelitian

\begin{tabular}{clc}
\hline Hipotesis & \multicolumn{1}{c}{ Pernyataan } & Hasil \\
\hline H 1 & $\begin{array}{l}\text { Menunjukkan bahwa Kualitas informasi secara segnifikan } \\
\text { berpengaruh positif terhadap kepuasan pengguna. } \\
\text { Menunjukkan bahwa Kualitas sistem secara segnifikan berpengaruh } \\
\text { positif terhadap kepuasan pengguna. }\end{array}$ & Diterima \\
H 3 & $\begin{array}{l}\text { Menunjukkan bahwa Kualitas layanan secara segnifikan } \\
\text { berpengaruh positif terhadap kepuasan pengguna. } \\
\text { Menunjukkan bahwa Kepercayaan secara segnifikan berpengaruh } \\
\text { positif terhadap kepuasan pengguna. }\end{array}$ & Ditolak \\
Henunjukkan bahwa Kepuasan pengguna secara segnifikan & Diterima \\
berpengaruh positif terhadap manfaat bersih
\end{tabular}

\section{KESIMPULAN}

Dari hasil analisis dan pembahasan pada bab sebelumnya, maka dapat disimpulkan bahwa :

a. $\quad$ Yang menjadi permasalahan dalam penelitian ini adalah belum diketahui apakah sistem informasi yang di kembangkan di STKIP MPL dapat melayani proses kegiatan akademik dengan baik.

b. Penelitian ini dilakukan untuk mengetahui faktor-faktor yang mempengaruhi kesuksesan implementasi SIAKAD di STKIP MPL, dengan menggunakan model kesuksesan sistem informasi yang dimodifikasi dari model kesuksesan DeLone \& McLean. Proses validasi dan reliability model serta pengujian hipotesa menggunakan Structural Equation Modeling (SEM) yang di analisis menggunakan software Amos 20.

c. Dari hasil analisis data yang dilakukan terhadap user SIAKAD, didapatkan hasil bahwa kualitas informasi berpengaruh terhadap kepuasan, kualitas sistem berpengaruh terhadap kepuasan pengguna, kepercayaan berpengaruh terhadap kepuasan pengguna, kepuasan pengguna berpengaruh terhadap manfaat yang dihasilkan SIAKAD, sedangkan kualitas layanan tidak berpengaruh secara signifikan terhadap kepuasan pengguna.

d. Berdasarkan penelitian yang dilakukan, didapatkan model akhir penelitian dengan 5 (lima) buah variabel beserta indikator-indikatornya. Indikator-indikator yang dihasilkan dalam penelitian ini merupakan faktorfaktor yang berpengaruh terhadap kesuksesan implementasi SIAKAD di STKIP MPL.

\section{UCAPAN TERIMA KASIH}

Ucapan terima kasih saya haturkan kepada:

1. ALLAH S.W.T atas segala Firman-NYA dengan karunia dan rahmat-NYA.

2. Orang tuaku yang sangat aku cintai dan sayangi, terima kasih atas dukungan dan do'anya.

3. Pendamping Hidupku..yang telah memberikan 2 Pangeran kepadaku.

4. 2 Pangeranku.. Adha Muhammad Al Fikhar dan Muhammad Rafi Al farizzi yang selalu memberikan inspirasi..

5. Adik-adikku yang sangat aku cintai dan sayangi, terima kasih atas dukungan dan do'anya.

6. Untuk semua orang yang tidak dapat penulis sebutkan satu persatu, terima kasih atas do'a dan dukungannya. 


\section{DAFTAR PUSTAKA}

Al-Hakim, L., 2007. Information Quality Management: Theory and Applications. USA: Idea Group Publishing.

DeLone, W., \& McLean, E., 1992. Information Systems Success : The Quest for the Dependent Variable. Information Systems Research (3:1), 60-95.

DeLone, W., \& McLean, E., 2002. Information System Success Revisited. Proceeding of Hawaii International Cenference on System Sciences. IEEE computer society.

DeLone, W., \& McLean, E., 2003. The DeLone and McLean Model of Information Systems Success: A Ten-Year Update. Journal of Management Information Systems, 9-30.

Ghozali, Imam A., 2004. Model Persamaan Struktural-Konsep dan Aplikasi dengan Program AMOS Versi 5.0. Semarang: Badan Penerbit Universitas Diponegoro

Santoso, S., 2011. Structural Equation Modeling, Konsep dan Aplikasi dengan AMOS 18. Jakarta: PT Elex Media Komputindo.

Wang, R. Y., Storey, V. C., dan Firth, C. P., 1995. A Framework for Analysis of Data Quality Research. IEEE Transactions Knowledge and Data Engineering, 7(4), 623-640. 